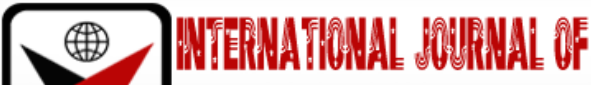

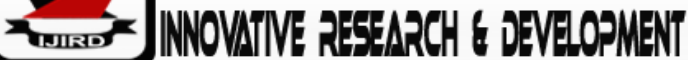

ISSN 2278-0211 (Online)

\section{Christian Missionaries' Influences on Öhna Traditional Institution in Ikwerre: Negotiating the Insider/Ouitsider Perspectives}

\author{
Dr. Ndidi Justice Gbule \\ Senior Lecturer, Department of Religious and Cultural Studies \\ University of Port Harcourt, Nigeria
}

\begin{abstract}
:
There is an increased awareness to retain some traditionalinstitutions of Africa. This is because substantially Africa has been maimed and dehumanized by the Christian missionaries andtheir protégés as one whose footmarks are not in the sands of time. This narrative fostered the illusionary views that Africa has no history, culture, no religion, and of course, no ethics. However, there arevital institutions and structures which sustained the African before the arrival of Europeans and literacy skills, among which is the Ohna traditional institution among the people of Ikwerre of the Northeastern Niger Delta. With the transformation of Christianity by the militant pneumatological type in Africa in the 21st Century, there seems to be a completeeffacement of traditional beliefs and practices. This work examines the story of Öhafrom the perspectives of the insider against the resurgence of Christianity today. Making use of historical research, and supplemented with ethnographic data, the paper avers that Öhna is alive and well despite the outside factors which tendto occlude it into obscurity. The paper is sanguine that what is needed is dialogue and mutual enrichment of both the Öhna and Christianity so that Christianity will find resonances with Ikwerre forms and metaphors and Ikwerre people will not suffer identity crisis or belongingness
\end{abstract}

Keywords: Ohna, Christianity, Christian identity, Ikwerre, Dialogue, Insiders and outsider

\section{The Insider/Outside Discourse of Ohna Traditional Institution in Ikwerre}

The Ikwerre people also known as Iwhuroha are located in the Northeastern part of the Niger Delta in Rivers State, Nigeria (Mackenzie, 1932:2, Talbort, 1967:15). K.O. Amadi ((1993:34-38) opines that the position of Ikwerre is uniquely strategic as a 'frontier society between the peoples of Igbo hinter land in North and the Niger Delta city-states in the South. The demography and social index are also unique. Located between longitude6.4 and 7 East and latitude 4:45 and 5,15 north, the population of Ikwerre is about 2.4 million people, with an area of 32,000 kilometers that is 29 clans, and $20 \%$ which is urban. Ikwerre people are predominantly farmers, even though their others who engaged in other occupation largely for subsistence. Its main city Igwuocha (Port Harcourt) is cosmopolitan because of migrant workers in the Oil and Gas industries. The Ikwerre speak Ikwerre language, which is cluster of Igbo and Ogbah or 'Igboid' of the Benue-Congo linguistic group. It is this interaction of rural and urban life that puts Ikwerre in a strategic and unique position among other groups in the Niger Delta.

The dynamics of Ikwerre indigenous society show that it is decentralized and segmented. There is no centralized authority like the Yoruba of the Southwestern Nigeria. Accordingly, scholars have identified four political organizations common to African states. These are (1) kinship-based authority, (2) kinship and association authority, (3) kingship authority, and (4) consolidated centralized authority. Yet others have collapsed the above systems into two categories, namely the centralized system and decentralized systems (Fortes and Pritchard, 1940). The latter category is sometimes referred to as 'stateless societies'. Robin Horton asserts that they are stateless because it is difficult to point to an individual or group of individuals as the rulers (1972:72). However, this does not suggest the absence of leadership, nor does it indicate a lawless or undisciplined and backward people as some outsiders have concluded (Njoku, 2008:159). The Ikwerre people belong to the segmentarysociety that are held together by a pervading influence of kinship and religious ties (0.0 Wobasi, 1993:51). The principal structures of social living and political mobilization are built around the family (ezi-nuoro), compound (rumunda), village (ngbu), and the clan (mbam) in the absence of centralized political leadership. It is in this context that the institution of Ohna or the Council of Elders is a significant feature of Ikwerre traditional government. EleOhna (Council of Elders) is the highest political, legislative and judicial body in Ikwerre. Each Ikwerre community has its own Ohna (Mackenzie, 1932:14-15). Membership into Ohna is representation and the Ohna holds office for life unless he acts contrary to the shared customs and traditions (Omenueli). Only the eldest males from each lineage or compound (rumunda) are eligible to become members. Membership into Ohna or the Council of Elders is by ascription. In other words, the Ohna person assumes the position regardless of his achievements or desire. As longs as he does not 
denigrate the shared values and ideals of the community, he remains the Ohna throughout his life. Perhaps this may explain why slaves, strangers and persons of vile of character are not eligible to become members of the Council of Elders (Ohna). The Ohna person is the embodiment of right living and a symbol of all that is noble and salient in the Ikwerre traditional society. Therefore, to be initiated into Ohna is to be inducted into a spiritual world of encyclopedic inclusiveness. The visibility of this assertion is captured in the paraphernalia the Ohna is associated. The Owhor stick he carries symbolizes his power and authority and a manifestation of his close ties with the departed ancestors (rukani) or the living dead (Mbiti, 1969:83). Although the permanent state of the ancestors is said to be in the underworld yet they are thought to be one community with the living. The ancestors play a vital role in the affairs of Ikwerre people. As the intermediary between the living- dead they are believed to help the living members procure the good things of life, and deliver them from the existential problems of life. Thus to John Mbiti (1969::83-84), the ancestors are the guardian of the family affairs, traditions, ethics and activities...Because they are still people, the living-dead are therefore, the best group of intermediaries between men and God. They know the needs of men, they recently been here with men and at the same time they have access to the channels of communicating with god, directly or indirectly through their own forefathers. Therefore, men approach God' (Mbiti, 1969:83-84). It is this belief that props up the ritual practices associated with the second burial ceremonies, reincarnation, libations and offerings towards the dead. In Ikwerre, as in most African communities, the notion of the ancestral cult is very strong. This is because in Africa one's success in life is causally influenced by the spirit world. Thus, health problems, crop failures, and personal problems are attributed to the manipulation of the ancestors (Mullins, 1998:23).

The Ohna or lineage elder is also the custodian of the Owho-ugwu, the apotheosized insignia of office. The Owho nu ogwu once it is invoked symbolizes social justice, high moral standards, retribution as well as fair play. The Owho nu Ogwu ritual object encompasses the moral corpus for the traditional Ibo and Ikwerre peoples. With it the Ohna or the lineage elder blesses, settles disputes, administers oath, as well as exercises social, political and moral authority over his kindred (Ejizu, 2008:32).

The Ohna is therefore highly revered in Ikwerre traditional society. However, with arrival of the Pentecostal/Charismatic Churches among some Ikwerre communities, the Ohna institution has badly denigrated. The question is how does the Öhna traditional institution, a veritable instrument of social control and peace-building dialogue with Christianity? What are those beliefs and practices which Ikwerre converts to Christianity jettison? Whichever values of Öhna do Ikwerre Christians find parallel to Christianity, especially at the ideational level. Is it possible for Ohna traditional institution to survive without its political and traditional moorings? Are there some salient values in Ohna which can be integrated into Christianity so that the Ikwerre people can practice Christianity without pretense? These are the dialectics which this essay problematizes. It is therefore an insider's views of how the ordinary, "unimportant' people of Ikwerre operated within their culture; what influences them and what they can or cannot influence; how they see their role in society and how the others see it. In other words, it is history from the underside and not from above.

\section{Eligibility into Öhna Traditional Institution}

To qualify for the membership into Ohna one must be freeborn (or Di-eli) as well as the eldest male of lineage. The choice of who is eligible resides in the compound (rumunda). In addition, he must be knowledgeable in the moral norms and traditions (ome-nu-eli) and be an initiate of an age grade in the community. The osu (or outcasts) are not eligible. They are regarded as persons sacrificed to the gods and so are cursed. Ohna is still in-force. The reason why such social stigma (Osu) persisted is outside the burden of the essay. Other conditions for eligibility are that the persons are not suffering from deadly diseases like leprosy, epilepsy, Tuberculosis. People who with these illnesses are regarded as ritually unfit for Ohna or the Council of Elders. The nominee must be morally circumspect. Criminals and vile persons or persons on sanctions by the community are forbidden from membership into Ohna. He should be a man whose 'words are his bond: This is because Oha men are the custodians of the traditional ideals enjoined by the Earth goddess - Ali. Therefore, any man who emerges from this inquiry with a clean sheet is considered eligible for membership.

\section{Stages of Initiation into Õhna}

The rituals of initiation into Ohna are principally divided into three stages, namely: the initial consultation, the presentation of the nominee to the 'EleOhna' (Council of Elders); and the last stage known locally as 'Okpu-te-Okpu' (Coronation).

Although the first two stages are essential to becoming a member of Ohna, the last stage is the most important, as we shall see later.

The preliminary stage involves the visit of Ohna to the lineage where the next Oha man would come from Such 'visits' are normally prompted by the vacancy created by a former incumbent's death. Though the lineage must have a fore knowledge of the intended visit of Ohna, they will feign ignorance by custom. This is to accord it the surprise and apprehension people hold whenever Ohna visits a compound or a lineage. When such visits are made, the people know immediately that something untoward has happened. Examples include murder, incestuous acts, accidents and other taboo.

The lineage receives the Ohna by offering them fried fish/meat called 'Okwu-use' accompanied by a bottle of local gin and a jar of palm - wine, jointly referred locally as 'karama-nu-kana'. Kolanuts and alligator pepper are also served which act as stimulants during the time of deliberation.

Ohna requests the lineage to give them another 'friend' to replace their deceased member. The lineage solicits for a two - week respite known as 'esa-to' within which they would be able to present to Ohna their nominee notably the eldest male from the lineage. But before Oha departs, it is customary that 'ewai-ise' (fifty kobo) be given to them. This is 
the charge made on 'ovu-lizookpoko' (which literally means 'carrying up of their seats'). This amount is paid as many times as the Oha visits the lineage.

As the Ohna departs, the lineage withdraws into a serious meeting to resolve on who their next representative in Ohna would be. The initial inquiry involves the investigation of the person's health. Whether he's someone with a se mind. More importantly, his moral uprightness is enquired as well. But if the person is wanting either morally or health- wise, the next senior in rank who jumps these hurdles is chosen as their next Nye Ohna. This inquiry is welcome; for it will ensure that the right calibre of individuals is chosen thereby fostering the good image of the institution. A community where everybody knows one another morally and otherwise, the choice of an honest person is made possible and easy.

The second stage starts at the expiration of the fourteen days grace. This time the Ohna is invited. After the formal eating and drinking that accompany the visits of Ohna, the nominee is presented to Ohna. He is cheered and congratulated by the members of Ohna, welcoming him to their sacred fold. 'Nye-risi' Ohna (the leader of Ohna) enumerates to the nominee the 'dos and don'ts' of the institution which range from being morally circumspect to the observation of certain dietary regulations. For example, he is net to be found guilty of murder, incest, theft, perjury, etc. Among the dietary regulations include the abstention from eating reptiles as snakes, foo-foo (fermented cassava) and cocoayam. He also should not eat from dishes and with Western cutleries. This is not unconnected with the fact that as custodians of tradition, Oha cannot afford to dispense with their cultural ideals entrusted to them. Pounded yams, instead of cocoayams and foo-foo, is to be eaten because it reflects the high status enjoyed by the institution. And he is to eat from $n k p u r u$ (small wooden mortar) with laddles.

But nowadays these dietary rules are not strictly upheld. An Ohna man could eat whatever he likes and from whatever he chooses in the privacy of his home. But he abstains from them while eating at public meetings. This change is most welcome. It shows the adaptive nature of Oha and a sure indication that the institution will survive in the future.

Apart from these regulations, the nominee is enjoined to perform the ceremony of 'Okpute-.okpu' (Coronation) at the earliest possible time.

At this stage the nominee could be called an Ohna man and could take the title 'Ohna" before his name. Or, he could personify the name of his lineage since he represents the collective will of his people and the sanction of the ancestors. For example, OhnaRumuagiri, OhnaRumuiyoro representatives of the lineages Rumuagiri, and Rumuiyoro, respectively. However, the nominee is not a full-fledged member since he has not been publicly crowned. Hence, he does not enjoy the full privileges of Ohaship. For instance, at the communal sharing of things, say meat, he is given whatever portion the Oha chooses. He cannot reject if the share is relatively small.

Besides, in event of his death, he is not given full funeral rites as befitting an Oha man*. In fact, frequent ridicule is often lurked on such families who for financial reasons failed to perform the rituals involved, so that when he dies, he would be accorded full burial rites; and consequently, achieves a blissful rest in the ancestral world.

The third and last stage is 'okpu-te-kpu' (Coronation). As indicated in the preceding paragraphs, it is the most important of the other two stages. This is because of the privilege's contingent on its performance. The coronation ceremony is normally an occasion of great rejoicing. It usually takes place on 'Nkwo-ehieri' (the name for one of the week days). It is observed as the traditional holiday when titled men are exempted from heavy manual labour. This accounts for the huge crowd attracted whenever the coronation ceremony is taking place. To signal the commencement of the ceremony seven can-on shots are fired. The Ohna people are shown a comfortable corner of the village square where the ceremony is taking place. They are served their usual food which includes a bottle of local gin plus a jar of palm wine, Kola - nuts and alligator peppe. Meanwhile, two native pots, locally known as 'ite-owbu', with white chalk (oro) painted round them are filled with palmwine for the Ohna They dip in their 'ahea' (ivory horn) and drink to their fill.

The village square where this occasion is normally staged: is thronged with people from different walks of life owing to the wide publicity given to it. Distant relatives and friends, in-laws and well-wishers bring food drinks, and other items to entertain quests. Different kinds or hits of traditional music are played inviting me and women to dance. The entire arena is some-what charged. Guests, friends, in-laws and well-wishers toss coins to the dancers as they riggle their waists in such a frenzy that is beyond expression.

At sunset, the person acceding' to membership of Ohna adorning in a superior 'agbada' and expensive 'George' wrapper with beads hanging down loosely on his neck is paraded round the village square amidst cheers and claps. After that he seats centrally on the stool specially decorated for such an occasion. The nye-risiOhnathen moves forward to start the rituals of okpu-te-okpu. He takes up the nominee's staff of office known as 'nkpara' in his left hand and libates with the other hand as he recites these rituals:

Ikwerre: 'Chinekegozinkparawa nu nyenwa.'

English: (God, the Creator, bless the staff of office and the holder)

Ikwerre: Gozimako-anyi vu EleOhna'

English: (And bless us too the Council of Elders)

The nominee then stands up to receive the staff of authority as the ritual elder (NyerisiOhna) recites the following rituals:

Ikwerre: 'OhnamgbuObellei'toluneyemnkparawa.'

English: (OhnaObelle of nine lineages are collectively giving you this staff of authority. ou will be in possession of it till old age).

Next, nye-risiOhna (or the ritual elder) takes the red cap known as 'okpuwagoro' and touches it four times on the ground soliciting the blessings of Ali (the Earth goddess)in these rituals:

Ikwerre: 'Ali ehina- okpuwa.'

'Biko, nyenweokpu-wayakankagbuoku.' 


\section{'Oyiokpukaokpuwa.'}

English: (The Earth goddess see this cap,

Please, let the owner wear it till old age.

It must be worn out by the owner').

Simultaneously, he places the cap on the head of the nominee and recites these rituals:

Ikwerre: 'OhnamgbuObellei'tolu nu okpusiokpuwa.'

'Okpukaokpuwa-kaka-nkagbu Oku.'

English:('Ohna of nine lineages are collectively adorning you with this cap.

(This cap will be worn till your old age').

It is instructive to note the significance of the numeral symbolism in the ritual practice. In Uvuawhu the number four signifiesperfection. The use of the number four is pressed into action in the salutation of chiefs or in public gatherings. Hence it iscaptured in forms like " Ekelaezebumgbaano (The greeting of a Chief is four times). Most people uninitiated in their customsand traditions (ome nu eli) have fallen foul and fined.

At the end of these rituals traditional dances of various kinds resume at fever-heat. The newly completed byeOhna dances round once more. Gifts of cash, wrapper, livestock, and others are given to him. The merry-making ends in the evening. Guests, in-laws, friends and well-wishers are entertained by assortment foods and drinks. It is therefore because of the elaborateness and expensive nature of this ceremony that many persons acceding to membership of Ohnadiffer it to a later date when they have the means and. material to do so.

\section{Rights and Privileges of Membership into Öhna}

To be initiated into Ohna is to be initiated into a fascinating world of behaviour and authority, a world of almost an encyclopaedic inclusiveness. It is one of the priciest things in the community that any aged male hopes to achieve in his life-time; for to be Nye-Ohna (a member of Council of Elders) confers a measure of honour and dignity. Because of his age, Nye-Oha is looked upon as a man of reliable character, tact, integrity and sound judgment; a man in favour with his people, able to build a large following. Consequently, the privileges he enjoys are many. His person is deemed purified and sacred. There is therefore something of a priestly attribute about him in consonance with the Nnoka deity to which he-minister. His wife is treated with special honour and if adultery is committed with her, it is on the pain of heavy placatory rituals. In fact, in the old days, such offences were committed at the risk of exile, or slavery, or was even, death. An Ohna man is not to sleep outside his home, nor is he expected to keep vigil during funerals. In addition, Nye Ohna is exempt from communal labour and fro some form of manual labour. Generally, he is forbidden from climbing trees, digging graves, carrying corpses, etc. He is also immune from bodily harm, and from being fettered in any manner should the necessity ever arise. It is therefore suicidal for anybody whether by omission or commission to inflict injuries on Nye ohna man. Furthermore, whenever the Ohna people are on procession along the main roads, women are not expected to walk across them. This caution is enjoined because it is impossible to determine the woman who is menstruating. Thus, to ensure that the sacred personality of Nye-Ohna men is not defiled, women are forbidden from walking across them while the Ohna is on procession. The above privileges notwithstanding, Nye-Oha has other special insignia. His shoulder bag which hangs loosely over his left shoulder while on a journey contains 'ekwu-uwhie' (laddle);'ahea' which he drinks from, 'nfu' (an ivory horn), 'owhor' (a special portable tree trunk for oath-taking), oro-nu-odo (white chalk and camwood). The insignia contained in the shoulder bag helps to render him less vulnerable to evil machinations of other and ancestral spirits. In fact, the Ohna cannot go anywhere without the shoulder bag. In the shoulder bag therefore embodies cosmic reality as it is from there the Ohna draws sacrality and power. With it he mediates between the worlds of the living and the departed ancestors. He could tell the future and pronounce judgement on difficult cases like witchcraft and sorcery. In some African communities the shoulder embodies worldviews or ritualizes life. Accordingly, there are many ways the shoulder bag is perceived; as a human artifact, or as a social index or as a symbol of cosmic truth. All of these realities are present, but it is the transcendent and the cosmic that comes first (Evan Zuesse, 1985:6-7). In Ikwerre the shoulder bag adorned by the Ohna (or the Council of Elders) performed all that is noble and sacred in the people's thought. As the ritual leader of his community, the Ohna took the first share during communal sacrifices. He also took the lead in social functions like the New Yam Festival, the coronation of chiefs, and. other ceremonials that involve the re-enactment of the people's culture, Thus in his capacity, he acts as a perpetuator of the traditions, practices, beliefs, and usages of the community, referred to as "omenu- Eli".

As the ritual leader of his community, he took the first share during times of communal sacrifices. He also took the lead in social functions like the New Yam Festival, the Coronation of Chiefs, and. other ceremonials that involve the reenactment of the people's culture, thus in his capacity, he acts as a perpetuator of the traditions, practices, beliefs, and usages of the community, referred to as 'omeritual but the privileges conferred on Ohna call for certain obligations on their part. In the community, therefore, Ohna plays a significant and decisive role in the government of the town. As earlier mentioned above, Ohna is a representative government in Ikwerre. Similarly, in the administration of justice the democratic approach is used. The making of laws, the settlement of quarrels between individuals, lineages, and the punishment of offenders were not left in the hands of a select jury but to the entire Ohna. They hear from the disputants and they withdraw and thereafter consult among themselves, locally referred to as 'Ogbaizuzu. They return with a verdict which is unanimously acceptable to the parties, the entire villagers, and the departed ancestors. The decision of the Ohna is taken as the final judgment, and no one dare appeal against it. Thus Ohna within the Community is the supreme judicial body. Meanwhile fines are imposed on the guilty party usually paid in kind (goats, cows, - fowls, wine) and cash. The various lineage heads and the various age-group associations act as police force, implementing its laws and order, including the recovery of debts, maintaining peace between lineages, and restoring order after fights had erupted. Besides 
the imposition of fines on the guilty parties, Ohna also employed various sanctions in exerting its authority on the community. Among these are, boycott of the persons concerned, embargo on the use of his/their property (Otu se)and distraint upon his/their property (Ohi-ogwu).

Where however, the Ohna is unable to reach decisions in cases of grave crimes or disputes, oaths are procured, and the accused made to swear by them. It is believed that if he is guilty within months he must die. But after a year from the date the oath was taken nothing happens to him, he is declared innocent and vindicated by set cultic methods. From the above inference, it is manifest that decisions in Ohna are reached by consensus. Through this process Ohna exercised jurisdiction in civil and criminal cases, regulated customs and promulgated laws which help to maintain peaceful and humane co-existence within the community. Judicial functions apart, Ohna holds annually religious divinations to determine whether the town retained the divine favour of the ancestors/gods. This is known as 'ovu-ekperi-kpa-eha. If it is divined that the gods/ancestors are angry, they are placated so that the community retains the favour or pleasure of the divine, or sacred realms. For instance, in the late 70's when the number of people in Uvuahu clan involved in motor accident assumed a greater proportion, the Ohna men consulted oracles and sacrifices were offered to appease which ever gods were offended. However, it is uncertain whether the cases of accidents within the community have reduced

The Ohna man's house is something of a sanctuary. If any fugitive sought asylum there, he is protected from immediate harm. The nyeohna wields a high prestige. On the contrary, if an Ohna man offends, his punishment is severe and condign. Thus, as the fountain of honour, he is expected to encourage loyalty and service by being morally earnest. A higher standard of behaviour is demanded of him than others. He would be expelled from the institution and condignly punished if found guilty of say theft, incest, murder, perjury, etc. In this way the members of Ohna always saw to it that discipline was maintained and the good image of the institution upheld. In his lineage at home, he presides over village councils and officiates large sacrifices. He also exercises certain priestly functions since he ministers unto the ancestral deity locally referred to as 'onu-ovodo'. He also decided difficult cases within his family and saw to it that his verdict is not prejudiced, but fair and just. Generally,' the Ohna in all their respective functions and capacities are men who have attained a uniquely prestigious position as the religious social and political leader par excellence. Nothing can better reveal the dignity and prestige nyeohnathat the rituals of death. Any Ohna man who has performed the set ceremonies for initiation into Ohna is accorded the most honoured funeral rites within the community. Because he is a man of high social status, his death is celebrated and he is normally buried in his 'ivari' (hall). In the past when human sacrifices were rife, it was customary to capture human heads for his burial, but nowadays things have changed, oats, cows and chickens are now used as surrogates. When an Ohna man dies, his death is not immediately announced until the members are informed through the leader (Nye-risi). He then gives the approval of sounding okwo-ike' (a wooden gong for emergency). This is greeted with loud cries and the booming of canon shot. The entire community then enters a solemn mood. No one dares attend to other chores, except those connected with the burial rites. The wives and daughters ('Omurinya') of the deceased family fetch from his farm and barn firewood and yams for the extensive cooking involved. In the night wake-keeping is observed as the corpse liesin state. Food, wine, and dances of various hits are moderately supplied. Funeral orations are given by the deceased family, his age group, and friends spelling out the good works the deceased would be fondly remembered for. The funeral proper starts very early in the morning with a canon shot, and sympathizers of in-laws, agegroups, friends both far and wide surge into the deceased family singing dirges armed with cutlasses. They display feats with scintillating vivacity. Their faces painted with ashes and charcoal and dressing to look fiercer than a man in a cannibal festival. All the plantain stems and trees within the vicinity are neatly combed. The songs san carry with them airs of holiness capable of moving the most weakling into action.

It is on this day that the Ohna people arrive. They are quartered in a compound next to the decease. The reason is to avert the evil eyes of the deceased ghost that is hovering around from harming them They are served with palmwine and locally brewed gin with fried meat fish to taste.

The whole arena is now thronged with mourners and sympathizers from all of walks of life. This is in keeping with the Ikwerre proverb which says nyeomesirunwibeagia-a' (A person who is bereaved/in trouble, others console him).

In the meantime, the corpse is decently dressed and laid - in state for people to watch When the corpse is ready for burial normally at sun - set, the oha file towards the place the corpse is lying — in state, Nye risk Ohna' (the head of Oha) spreads a white linen (ocha-se) over the coffin and recites the above rituals:

Ikwerre: "Kpaaigbugeokulekwereenya

Onwebyeichohia"

English: (Since you died without staying long with us

Go in alone and in peace.

Don't call for us).

After the recitations, the corpse could be lowered into the grave. As the coffin is being put into the grave, twentyone canon shots are fired; thus, signaling the departure of the dead and his transportation to ancestral spirits. The decrease is buried in his full insignia except the staff of authority ('nkpara). This is jealously kept in a corner of his 'ivari' (hail) to remind posterity the post the departed held during his life-time.

The funeral terminates at the end of the eighth day. On this day, the 'kpa-ka-kpa' men (a metal cross-bar wrapped with expensive 'George' wrapper and carried by two able-bodied men) perform feats that dumbfound human description. This is called 'oso-okwu'. People toss coins at them in appreciation. It is believed that these are not literally feats within human power, but a manifestation of spirits' power.

In the community today, the carrying of kpa-ka-nkpa for a deceased oha is growing lesser in importance. This is because it is lavish and expensive and therefore depends on the means and material to do so. Another reason is the 
prodigious growth Christianity is making in the community. Families that are ardent Christians brand it 'paganistic' and so untenable in the light of Christian tenets ad principles.

Late in the evening, the heads of the wives and children of the deceased are clean shaven, they are thereafter to wear mourning dresses, normally black colour until the second burial is performed. They remain confined to their homes for some period. The period of confinement is determined by the means and material to perform the second burial rites. But it ranges between six months to one year. The second burial is intended to make the deceased secure an eternal place and rest in the realms of the ancestors. Thus, the earlier it is performed the better for both the living and the dead. People also believe that it cannot be evaded without regrettable consequences. 'It is believed that until it is performed, the dead do not enjoy the full privileges of the dead, and not able to intercede for the living. The dead man himself will be unhappy; he is a homeless wanderer since he has not been offered a permanent place in the spirit world. In the alternative, he will persistently haunt his former dwelling place, and assuredly bring calamity on his family for such unfeeling and unwarrantable negligence. 'The family of the deceased perform the second ceremony on any agreed date after the period of confinement. This is marked with great festivities. Visitors from all walks of life and various stations, friends both near and distant come to grace the occasion. The merry-making terminates at 1:sk. Friends and guests are lavishly entertained. The bereaved family once more shave their heads and can now throw off their ro1'ning clothes without incurring the wrath of the departed. This second burial ceremony in Obelle is called 'Omesa-ehua. The family of the deceased now feel secure that they have paid the greatest honour to the dead who must always ensure their continued protection from any spiritual harm

\section{5. Öhna and Christianity: A Dialectics of the Insiders and Outsiders}

The Anglican missionaries were the first to have a firm foothold in Ikwerre land. And as yet, it is making a steady progress in its spirit of canvassing for new members (converts). Ikwerre is predominantly Anglican when compared with other Christian denominations, like the Catholics, Cherubim and Seraphim, to mention but two. Only a handful few of its population are Protestants. African Church historiography shows that communities along the coastline received the gospel message before passing on to those in the hinterlands. The Christian missionaries that Ikwerre communities were the Church Mission Society or the Anglicans. Prominent among the missionaries was Samuel AjayiCrowther, a Yoruba ex-slave. These churches were followed by the African Initiated Churches (AIC's) and Pentecostal and Charismatic Churches which have continued to gains in the 21st century.

The Pentecistal Charismatic Churches with their strict adherence to orthodoxy has made a tremendous inroad into Oha institution, so that the institution is now faced with the dilemma: how to adapt to the Christian ethics without losing its essential wholesomeness.

As indicated in the previous chapters Ohna performed a number of functions, notably oath-taking, divination and the consultation of oracles in times of crises. These served as means of social and political control. For example, an individual was meant in the past to swear on the 'owhor' (a special tree trunk for oath-taking) to justify a claim or prove his innocence when falsely accused. But with the subsequent establishment of the Christianity, the converts were taught never to swear on the 'owhor' but on the Holy Bible. This usurpation of function had underrated the community's system of control through Oaths, and had also influenced the tempo of social change within the community.

Because the rites of initiation into Ohna are hedged with many traditional religious rites, the Church educated their converts against becoming members of Ohna. This has affected the institution adversely. In the Community eligible Christian nominees into Ohna have either declined being members or given conditions under which they would become members. One of such, is the total removal of the Nnoka deity which an Ohna man ministers unto. Others include divination and the consultation of oracles, which they (converts) term idolatrous and superstitious, and so untenable in the light of the ethics of the Christian religion.

Worse still, others (converts) are obliged to become members of oha because of its professed moral ideals, if in the place of Nnoka deity, the Bible is substituted. This is really a big threat to the futurity of oha institution. The situation has left many a lineage without representatives in the oha. Consequently, these lineages are denied their fair shares in the communal sharing of things. In fact, my lineage Omuiyoro had once contended with this problem, but the situation was quickly redeemed when the next senior male in the lineage (Traditional Religionist accepted representing the compound.

Furthermore, before an oha was converted into the Christian Religion, he was compelled among other things to 'renounce his title and burn the insignia of the title as well as the cult objects associated with it.' Most of these overzealous converts in bid to becoming more overzealous and throw caution to the wind. Compelled by the church, they destroy other things associated with them.

Another area where the Churches had extended its domineering tentacles is the area of burial rites. Before the advent of the Christianity, it was customary to bury a dead oha man with slaves, or human heads. Such practices the people believed were to provide the deceased with a retinue of servants in the ancestral world, and to ensure his smooth entry into a permanent state of rest and. enjoyment of the ancestors. But the church aided by the colonial administrators had sent such a practice into the limbo of dead, memories.

The establishment of the church had also undermined old customs associated with the institution. The unimportance attached to the carrying of 'kpakankpa' at funeral- ceremonies of a deceased Ohna, besides its heavy financial involvement, isthe handiwork of Christian teachers.

With the acceptance of Christian faith by some oha men came the adoption of Western values and orientation. These have broken down centuries - old ritual taboos and practices, for instance, the practice whereby the oha consulted oracles to divine whether the community retained the divine favour of the gods, or God, is seen by the church as 'paganistic' and unchristian. In some lineages, some of them refuse attending Sunday meetings of Ohna because they 
conflicted with their Sunday worship. These attendant problems have played down the influence of oha today. Some fanatic Christians even refused forced labour enjoined by the Ohna within the community. These brand of Christians in their shortsightedness fail to appreciate the fact that these practices of oha had endeared the people humanely before the coming of the church. They erroneously dismiss such practices as superstitious, idolatrous, and so against the true ethos of Christianity,

Besides the negative effects of the church, the oha institution has gained a lot from the Christian religion. The church makes a positive enlightenment to traditional ideals and morality which oha tacitly enjoins. Acts like incest, murder, stealing, perjury, etc. are positively reinforced by the church. Thus, while the church denigrates the institution, it also seeks to re-valorize it.

\section{Concluding Remarks: The Way Forward}

Perhaps it might be pertinent to conclude this work by $\mathrm{x}$-raying the hopes and prospects of Oha Institution in the light of the change agents that are working.

Although Christianity with its attendant westernization has affected the sanctity of the institution theOhna institution will still survive.

Ohna had always stood, and still stands, as the palladium of our traditional ideals and practices. Traditional practices like naming ceremony, marriage rituals, funeral ceremonies, and other rites and customs are still reverently reinforced by the Ohna. In marriage ceremonies, the respective Ohnas in their lineages help in solemnizing marriages. Here they act as witnesses between the living and the dead, and therefore, give, the marriage a divine sanction. This vital function of the Oha has made divorce cases within the community few, if not absent.

Besides the inroads made by the forces of change, the mechanistic nature of the community is somewhat there. This aspect is, however limited to the degree of punishments meted out to those who deviate from the norms. Hence, persons guilty of incest, murder, theft, adultery, etc., are still expeditiously punished. But similar offences attract little or no negative sanctions in an urban centries where these crimes are rife. The sentences are normality of delivered by the Oha. Thus, as long as Ohna continues to perform these functions of social and political control, they are indispensable, and therefore, will survive.

Another obvious bet why Ohna will survive is the inability of the Christian Religion and Science to explain satisfactorily to the African minds the field of Cosmology. Explanations given in holy scriptures and textbooks are rather inadequate. Thus, there is the need to find recourse to our traditional beliefs which will supplement the gap created, hence there is a constant recourse by the African to fall back on his belief system in moments of crises. As William Bascom and J. Herskovit put it 'whatever their verbalization, Africans have by no means given over their allegiance to traditional supernatural forces when they accept -the deity of another people. Rather, the new is added to the totality of supernatural sources on which they can call for aid.' (quoted in OtontiNduka 1975:18). Consequently, Ohna will still persist in its divinatory roles, as the executors of the wills of the ancestors and gods, and as the custodian of tradition values and sanctions.

Moreover, since old age still matters in the Community, Ohna will exist. Generally speaking, everyone wishes to live to old age death and, subsequently, die a 'good death' Oha being the only institution within the community that confers a measure of respect and integrity to an old man, it will therefore survive Realistically, as long as old age is respected and revered, the institution will exist.

There are also the global interests among Africans to document what had endeared our forebears. This work Oha: An institution in Obelle is a sure manifestation of this global interest. Thus, there is the indication that with the documentation of most of our traditional institutions, which were not hitherto, the institutions will not suffer from extinction.

However, this paper does not intend to hold brief for Ohna Institution with regard to change. Humanity as a whole is dynamic' Ohna being a part in this whole cannot afford to be static. Change, therefore, becomes inevitable, if Ohna is to progress, or even survive. Ohna should not, therefore, be a parochial institution, insensitive to change; Ele-Oha should as a matter of priority jettison some of its traditional practices which were hitherto sacredly uncriticizable, but now untenable in the light of present-day circumstances. The in position of ritual taboos like, the eating of dogfish, foo-foo, the wearing of shoes at public places, the use of Western dishes and cutleries at tables, the riding of bicycles and automobiles, are all references to those practices that should be done away with. This, however, does not imply that Ohna should abandon its cultural moorings in order to sound modern because to do so would amount to committing cultural suicide, for as lionel Elvin points out, 'a people cannot accept every new influences uncritically and survive as a society'

In summary, Ohna will survive, but probably in a new garb, for it has within it 'an inexplicable seed of immortality' that has been planted and watered in the fertile soil of Ikwerre communities.

\section{References}

i. Amadi, K. (2003). "The Ikwerre People and their" in OtontiNdukaStudies in Ikwerre History and Culture, Vol. 2 Port Harcourt. University of Port Harcourt Press.

ii. Arinze, F. (1970). : Sacrifice in Ibo Religion Ibadan. University of Ibadan Press,

iii. Awolalu:, J.\&Dopamu, P. (1979). West African Traditional Religion Ibadan. Onibonje Press.

iv. Aylward, A. (1978), African Culture and the Christian Church London. Geoffrey Chapman.

v. Biesanz, M. \&Biesanz, J. (1978). Introduction to Sociology: New Jersy. Prentice-Hall, Inc.

vi. Broom, L. \&Selzinck, P.(1970). The Principles of Sociology; New York

vii. Fortes, M.\& E. E. Evans-Pritchard (1940). African Political Systems and. London. O. U. P. 
viii. Hasting, A. (1976). African Christianity; London. Geoffrey Chapman.

ix. Horton, R (1972). History. of West Africa. New York. Columbia University Press.

x. Ifemesia, C. 1979). : Traditional Humane Living Among the Igbo: An Historical Perspective Enugu, Fourth Dimension,

xi. Ilogu, E. (1974). Christianity and Igbo Culture New York. Nok Publishers (Ltd).

xii. Iwe, N.(1978). Christianity, Culture and Colonialism in Africa: Port Harcourt. RSNC.

xiii. Kalu, I. (1978). Christianity in West Africa: Nigerian Story; Ibadan. Day Star Press

xiv. Mackenzie, J. (1932). Intelligence on Rumuji Native Court. National Archives. Enugu.

xv. Mbiti, J.(1975). : An Introduction to African Religion, London. Heinemann.

xvi. Mbiti J.(1969). African Religions and Philosophy, London. Heinemann.

xvii. Mullins, M. (1997). "What about the Ancestors? Some Japanese Responsesto Protestant Individualism". Studies in World ChristianityVol.4 p. 41-64.

xviii. Nduka, I.(1975). Western Education and the Nigerian Cultural Background. Ibadan. O.U.P.

xix. Njoku, R. (2009). "Neoliberal Tradition in Precolonial Igbo Societies" in ChmaKoriehOlaudahEquiano and the Igbo World. New York. Africa World Press.

xx. Ofoegbu, R. (1976). Government for School Certificate Year; London. George Allen \& Unwin Ltd. 1976.

xxi. Ohaegbu, A. (1980). Nsukka Studies in African Literature. No. 3.Nsukka. U. N. N.

xxii. Onwubiko, K.(1973). School Certificate History of West Africa- BOOK 2. Onitsha. 4frican Educational Publishers.

xxiii. Parrinder, G. (1976). African Traditional Religion. London. Sheldon Press.

xxiv. Price, J. (1975). Comparative Government; London. Hutchinson\& Co (Publishers) Ltd.

xxv. Talbot, A.(1967). Tribes of the Niger Delta: Their Beliefs and Customs. London. Frank Cass

xxvi. Van der Zadem, J (1979). Sociology $4^{\text {th }}$ Edition. New York. John \& Wiley \& Son.

xxvii. Wobasi, I.(1993). Traditional System of Government and JusticeinIkwerre in OtontiNdukaStudies in Ikwerre History and Culture Vol.1. Ibadan. Kraft Books.

xxviii. Zuesse, E.(1985). Ritual Cosmos and Sanctification of Life in Aftican Religions.

\section{Appendix}

\begin{tabular}{|c|c|c|c|}
\hline No. & Name & Age & Place of Interview \\
\hline 1 & OhnaAmadiWokwerun & 78 Years & Omurila-Obelle \\
\hline 2 & OhnaAleraEjim & 69 Years. & OmagiriObelle \\
\hline 3 & OhnaAnadiWuche & 77 Years & Omuama-Obelle \\
\hline 4 & OhnaWamadiOwhor. & 80 Years. & Mgbere-Ibaa \\
\hline 5 & OhnaEmenikeWachijem & 80 Years & Omueze- \\
\hline
\end{tabular}

Table 1: Oral Sources 